JEL Classification: L 22; F 23; G 34

UDC 338.23:620.9

DOI: 10.30857/2415-3206.2019.2.9

\section{PECULIARITIES OF REFORMING THE ENERGY RESOURCES MARKET OF UKRAINE}

\section{SOLONENCHUK ${ }^{1}$}

${ }^{1}$ National University of Life and Environmental Sciences of Ukraine, Kyiv, Ukraine
Introduction. Ukraine is characterized by a certain energy dependence, as in most European countries, but its excessive dependence on external monopoly sources of fuel and energy resources has been and is one of the major threats to both energy security and national security in general. The main means to counteract these threats is to diversify not only the sources and routes of transportation of energy resources, but also energy technologies, the system of production and consumption of energy resources.

Hypothesis: introduction of the model of configuration regulation / reform of the energy market will allow to move to a climate-neutral development of Ukraine by 2050 within the framework of the program "European Green Deal", to significantly accelerate energy transformations.

The purpose of the study is to justify and develop practical recommendations for reforming the energy market in Ukraine.

Methods of research: statistical analysis - for comparative analysis and determination of dynamics of production and consumption of basic energy resources; system analysis - to substantiate and develop a model of configuration regulation / reform of the energy market.

Results: The dynamics of primary energy consumption are analyzed: coal, crude oil and petroleum products, natural gas, electricity / hydropower, nuclear, wind, solar, bio, heat. A systematic analysis of energy supply was carried out, optimistic, realistic and pessimistic forecasts of Ukraine's fuel and energy balance until 2035 were constructed. Developed and proposed to use a configuration regulation / reform model to implement energy market reform.

Conclusions: implementation of the model of configuration regulation / reformation of the energy market will allow to implement measures for rational use of energy resources, to reduce the energy intensity of the gross domestic product. The formation of effective tools for reforming the energy market will allow to implement the main principles of the Concept of "green" energy transition of Ukraine to 2050.

Keywords: energy market; energy consumption; model of configuration regulation/reform of the energy market. 
JEL Classification: L 22; F 23; G 34

УДК 338.23:620.9

DOI: $10.30857 / 2415-3206.2019 .2 .9$
ОСОБЛИВОСТІ РЕФОРМУВАННЯ РИНКУ ЕНЕРГОРЕСУРСІВ УКРАЇНИ

\section{І. СОЛОНЕНЧУК ${ }^{1}$}

${ }^{1}$ Начіональний університет біоресурсів $i$ природокористування Украӥни, м. Київ, Украӥна
Вступ. Україні властива певна енергозалежність як i більшості європейських країн, проте іï надмірна залежність від зовнішніх монопольних джерел паливно-енергетичних ресурсів склала i становить одну 3 головних загроз як енергетичної безпеки, так i національної безпеки взагалі. Головним засобом для нейтралізації цих загроз $\epsilon$ диверсифікація не тільки джерел i маршрутів транспортування енергетичних ресурсів, але $\mathrm{i}$ енергетичних технологій, системи видобутку та споживання енергетичних ресурсів.

Гіпотеза: впровадження моделі конфігураційного регулювання / реформування ринку енергоресурсів дозволить перейти до кліматично нейтрального розвитку України до 2050 року в рамках програми «Свропейська Зелена Угода» («European Green Deal»), суттєво пришвидшити енергетичні трансформації.

Мета дослідження полягає в обгрунтування та розробці практичних рекомендацій щодо реформування ринку енергоресурсів в Україні.

Методи дослідження: статистичного аналізу - для здійснення порівняльного аналізу та визначення динаміки видобутку i споживання основних енергоресурсів; системний аналіз - для обгрунтування та розробки моделі конфігураційного регулювання / реформування ринку енергоресурсів.
Результати: проаналізовано динаміку споживання первинних енергоресурсів: кам'яного вугілля, сирої нафти та нафтопродуктів, природного газу, електроенергії / гідроенергії, атомної, вітрової, сонячної, біо, теплоенергії. Проведено системний аналіз забезпечення енергоресурсами, побудовано оптимістичний, реалістичний та песимістичний прогнози паливноенергетичного балансу України до 2035 року. Розроблено та запропоновано для здійснення реформування енергетичного ринку використовувати модель конфігураційного регулювання / реформування.

Висновки: впровадження модель конфігураційного регулювання / реформування ринку енергоресурсів дозволить здійснити заходи щодо раціонального використання енергоресурсів, знизити енергоємність валового внутрішнього продукту. Формування ефективних інструментів реформування ринку енергоресурсів дозволить реалізувати головні принципи Концепції «зеленого» енергетичного переходу України до 2050 року.

Ключові слова: ринок енергоресурсів; споживання енергії; модель конфігураційного регулювання / реформування ринку енергоресурсів. 
Formulation of the problem. Ukraine, as a country that is increasingly involved in global processes of globalization and internationalization, faces high levels of competition both at the macro level and at the level of individual entities.

The inconsistency of the interests of the state, regions and individual economic entities within the country, the lack of a coherent effective strategy and outdated management methods adversely affect the competitiveness of the national economy and energy sector in particular. The existing threats to national interests and national security of Ukraine, defined by the Law of Ukraine "On the basics of national security of Ukraine" [1], are mostly related to inefficient use of fuel and energy resources and insufficient diversification of sources of supply. The implementation of a corresponding active energy conservation policy for ensuring the energy security of the state provides for an appropriate algorithm of actions and decisions that will allow to ensure a sufficient level of competitiveness, to implement appropriate measures for reforming the energy market in Ukraine.

Dynamics, scale and technical and economic indicators of social production, especially industry, depend to a large extent on the development of the fuel and energy complex and the state of the energy market. Existing fuel and energy resources are the basis for the formation of various trade and production complexes (TCEs), including industrial ones, determining their specialization in energy-intensive industries. For many years, much of Ukraine's domestic energy sector has been dependent on purchases of natural gas, petroleum products, and fuel for power plants (both TPPs and NPPs) in Russia. Import dependence has turned gas, oil, nuclear fuel and subsequently coal into levers of pressure on Ukraine from a neighboring state. The loss of fuel and energy complex facilities and promising areas for the development of hydrocarbon resources as a result of annexation of Crimea and hostilities in the East of the country, as well as the destruction of oil and gas infrastructure in Donetsk and Luhansk regions - new additional factors that have significantly weakened energy security the potential of the domestic energy market.

An analysis of recent research and an unresolved part of the problem. Most scientists agree that the regulation of the economy and, with it, the reform of the energy market - an interconnected and well-coordinated process [2]. The problems of state regulation of the fuel and energy complex and the reform of the energy market are devoted to the work of both domestic and foreign scientists: L. Belyaev [2], N. Mitsa [3], L. Tovazhnyansky [4], I. Franchuk [5] and others. Most of them agree that state regulation of the energy sector and reform of the energy market is one of the priority measures to improve the security of any country. Thus, the conceptual principles of regulation of the development of the fuel and energy complex and the market of energy resources are covered in the works of such scientists: O. Alimov,

A. Danilenko, V. Tregobchuk [6], 
V. Bakumenko, V. Knyazev, Y. Surmin [7], O. Amelnitskaya [8], D. Busareva [9], O. Vihrova [10]. However, the issue of creating and using effective instruments for regulating and reforming the energy market in accordance with the Concept of the Green Energy Transition of Ukraine to 2050 [11] remains unresolved and needs consideration and resolution.

The purpose of the article is to study the tools of reforming the energy market of Ukraine and to identify the problematic aspects in the functioning of the fuel and energy complex (FEC).

Research results. Currently, the energy market in Ukraine exists, and it continues to develop and develop further. There are a number of tools to ensure proper antitrust control to ensure its proper formation and strengthening. The key problem of securing the energy market and shaping a competitive national economy in the various commodity markets is the implementation of full antitrust regulation. The level of competitiveness of the domestic economy remains low, which poses significant threats to the country's energy market. At the same time, control over the energy market and the market relations within it requires the creation of wholesale and retail market rules, the development of systems and accessibility rules, the development of legal compliance documents, the prevention of manipulation of prices and capacities in the energy market. Let's carry out comparative analysis and dynamics of production and consumption of basic energy resources (Table 1).

Table 1

Comparison of dynamics of production (production) and consumption of basic fuel and energy resources for 2017-2018

\begin{tabular}{|c|c|c|c|c|c|c|c|c|}
\hline \multirow[t]{2}{*}{$\begin{array}{l}\text { Fuel and } \\
\text { energy } \\
\text { resources }\end{array}$} & \multicolumn{2}{|c|}{$\begin{array}{c}\text { Production } \\
\text { (production) of } \\
\text { energy resources, } \\
\text { thousand tons of } \\
\text { oil equivalent }\end{array}$} & \multirow[t]{2}{*}{$\begin{array}{l}\text { The ratio } \\
\text { of } 2018 \\
\text { to } \\
2017 \\
+/-\%\end{array}$} & \multicolumn{2}{|c|}{$\begin{array}{c}\text { Final } \\
\text { consumption of } \\
\text { energy resources, } \\
\text { thousand tons of } \\
\text { oil equivalent }\end{array}$} & \multirow[t]{2}{*}{$\begin{array}{c}\text { The ratio } \\
\text { of } 2018 \\
\text { to } \\
2017 \\
+/-\%\end{array}$} & \multicolumn{2}{|c|}{$\begin{array}{l}\text { The average } \\
\text { price, USD }\end{array}$} \\
\hline & 2017 & 2018. & & 2017 & 2018 & & $2017 \mathrm{p}$. & $2018 p$. \\
\hline Coal is coal & 13696 & 14087 & 2,8 & 5281 & 5944 & 12,6 & $78^{* *}$ & $77^{*}$ \\
\hline $\begin{array}{l}\text { Crude oil and } \\
\text { petroleum } \\
\text { products }\end{array}$ & 2208 & 2341 & 6,0 & 6 & 9 & 50,0 & $746^{* *}$ & $774^{* *}$ \\
\hline Natural gas & 15472 & 16487 & 6,6 & 14971 & 10599 & $-29,2$ & $6956^{* * *}$ & $6958^{* * * *}$ \\
\hline $\begin{array}{l}\text { Electricity } \\
\text { Hydropower }\end{array}$ & 12249 & 12295 & 0,4 & 10092 & 10203 & 1,1 & $52^{* * * * *}$ & $59^{* * * * *}$ \\
\hline $\begin{array}{l}\text { Total, incl. } \\
\text { other types of } \\
\text { energy } \\
\text { (nuclear, wind, } \\
\text { solar, bio, heat) }\end{array}$ & 58863 & 60413 & 2,6 & 49911 & 51171 & 2,5 & & \\
\hline
\end{tabular}

* for one ton; ** for one ton; *** per $1000 \mathrm{~m}^{3}$; **** MWh.

Source: compiled by the author on materials $[12 ; 13]$. 
The data in Table 1 indicate that the lack of own energy resources necessitates the import of energy resources from other countries. Such a situation raises prices for fuel and energy resources, including oil and natural gas. At the same time, according to Table 1, there are significant coal deposits in Ukraine, which proves the possibility to cover the state's energy needs at its own resources, create reserves and export its own energy resources. But the average cost of coal production is much higher than the selling price. That is, the coal industry is unprofitable, which requires considerable funds from the state for its modernization, re-equipment, acquisition of new technologies and equipment, attraction of investments for automation of coal production processes. Another energy-generating industry - electricity creates opportunities for electricity exports, but the high cost of production (availability in the cost structure of more than $80 \%$ of the cost of fuel, major repairs), there are problems of tariff formation and functioning of the energy market, which also relates to aspects of state regulation energy resources.

Taking into account the above facts, in the baseline scenario of the development of the energy market the following consumption of basic energy resources is forecasted by 2030 [12; 13]. Electricity consumption will increase by 2.2 times and exceed 395.1 billion $\mathrm{kWh}$ according to projected data, and export opportunities will increase to 25 billion $\mathrm{kWh}$ (Figure 1).

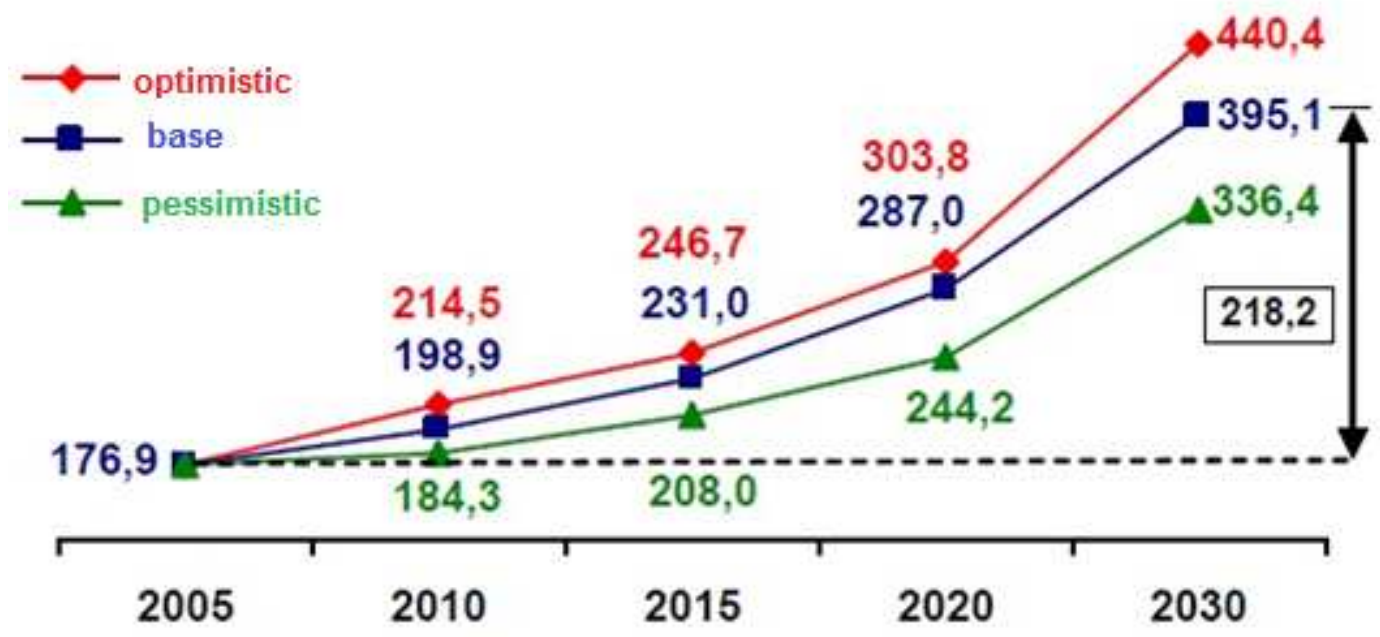

Source: $[12 ; 13]$.

\section{Figure 1. Electricity consumption according to forecast data}

Consumption of coal products will increase almost 2.2 times - up to 130.3 million tons (Figure 2).

Natural gas consumption will decrease by almost $36 \%$ to 49.5 billion $\mathrm{m}^{3}$ (Figure 3).

Domestic oil consumption will increase by one third - up to 23.8 million tonnes (Figure 4). 


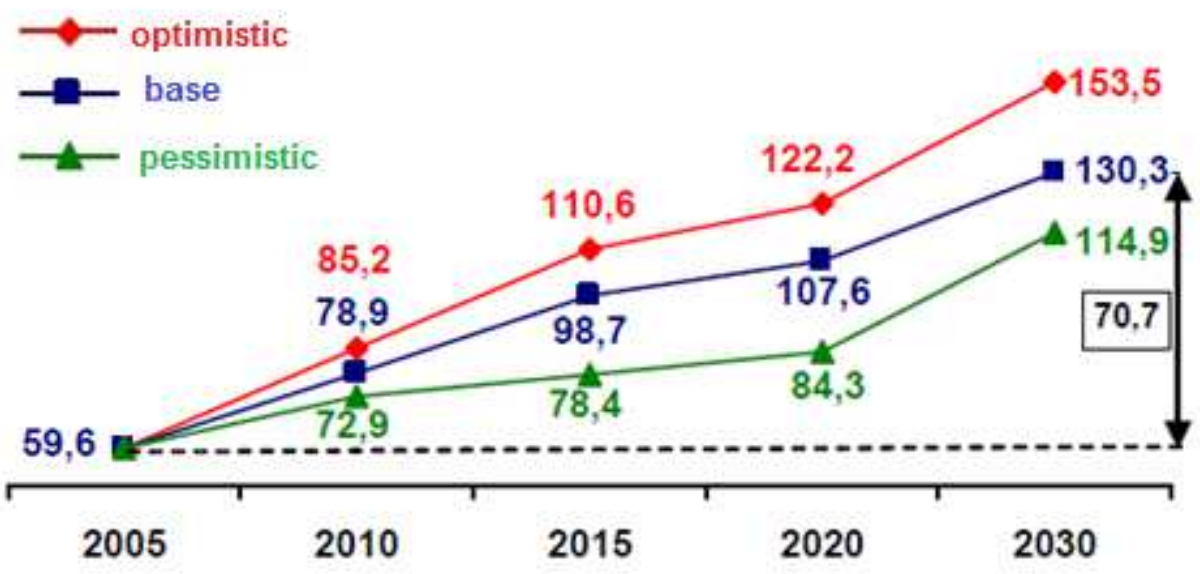

Source: $[12 ; 13]$.

Figure 2. Consumption of coal products according to forecast data

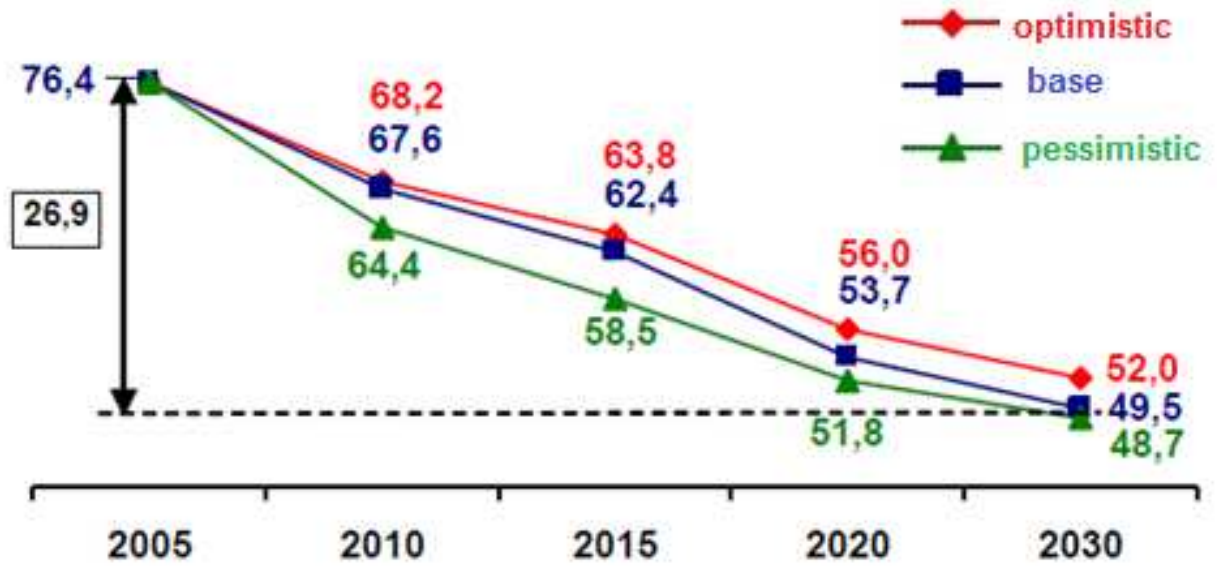

Source: $[12 ; 13]$.

Figure 3. Natural gas consumption according to forecast data

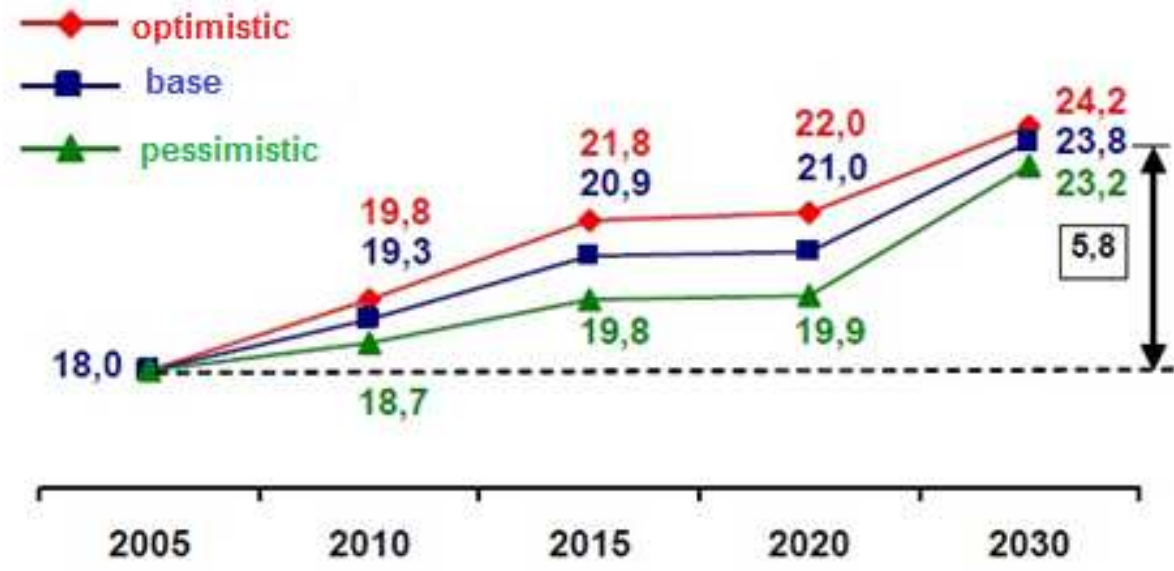

Source: $[12 ; 13]$.

Figure 4. Oil consumption according to forecast data

Estimated coal reserves in Ukraine amount to 117.5 billion tonnes, including 56.7 billion tonnes - explored reserves, of which energy brands -39.3 
billion tonnes. 6.5 billion tonnes of industrial, including almost 3.5 billion tonnes, or $54 \%$ of energy $[12,13]$. Due to the lack of capital investment in the coal industry, Ukraine has the oldest mine fund among the CIS countries, and its accelerated aging has led to the formation of a negative balance of production capacity. Reducing their volume has become a steady trend that is already catastrophic. For the period 1991-2015, the production capacity of coal mining enterprises decreased from 192.8 million tonnes to 91.5 million tonnes per year, or almost 2.1 times. At the same time, production capacity has been used only by $85 \%$ recently. Consumption of own and imported resources in 2015, 2030, mln tons/\% (Figure 5).

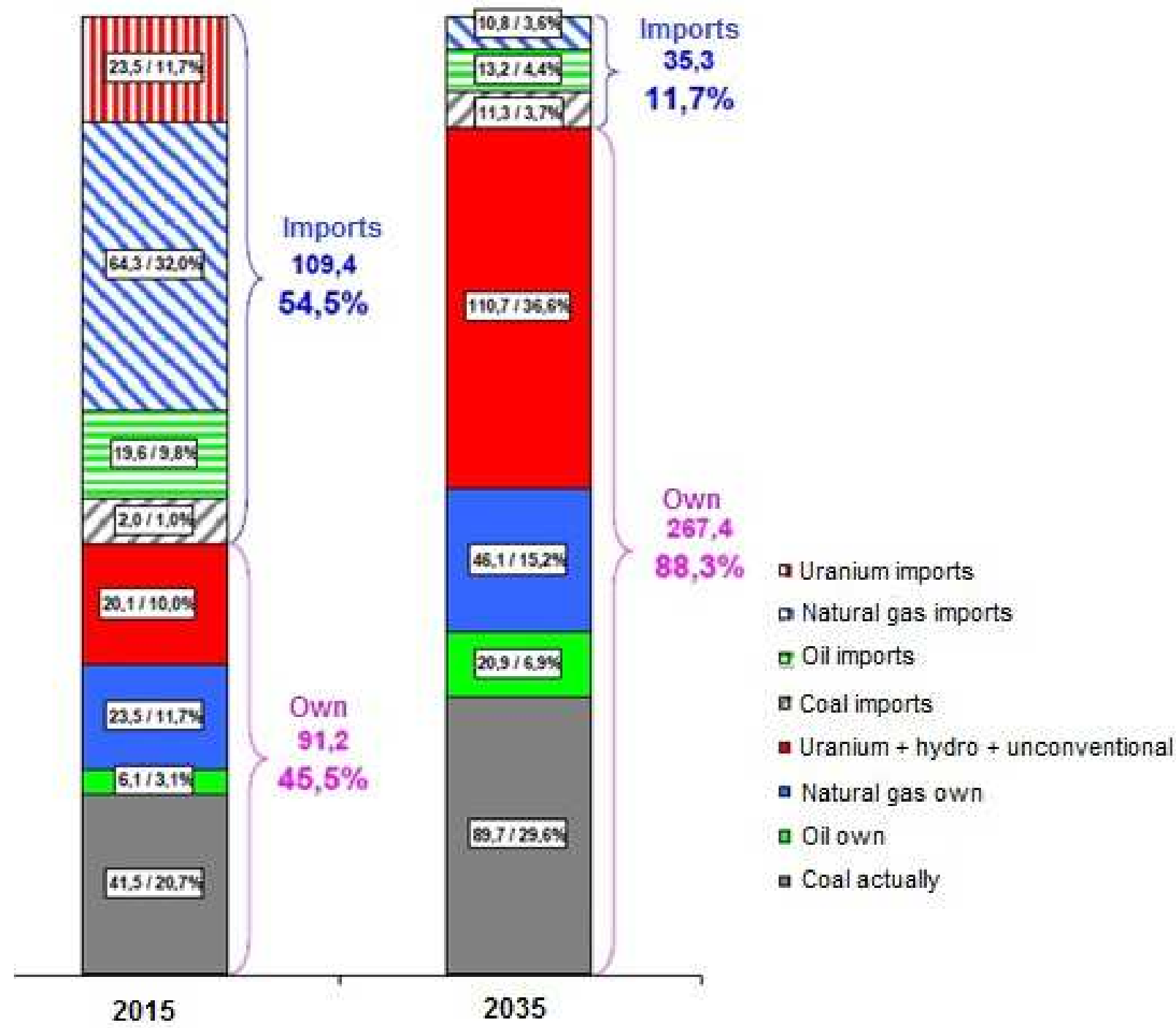

Source: $[12 ; 13]$.

Figure 5. Consumption of own and imported resources

In accordance with the identified trends in the development of the energy market, the projected fuel and energy balance of Ukraine until 2035 was constructed (Table 2). 
$\frac{v}{0}$

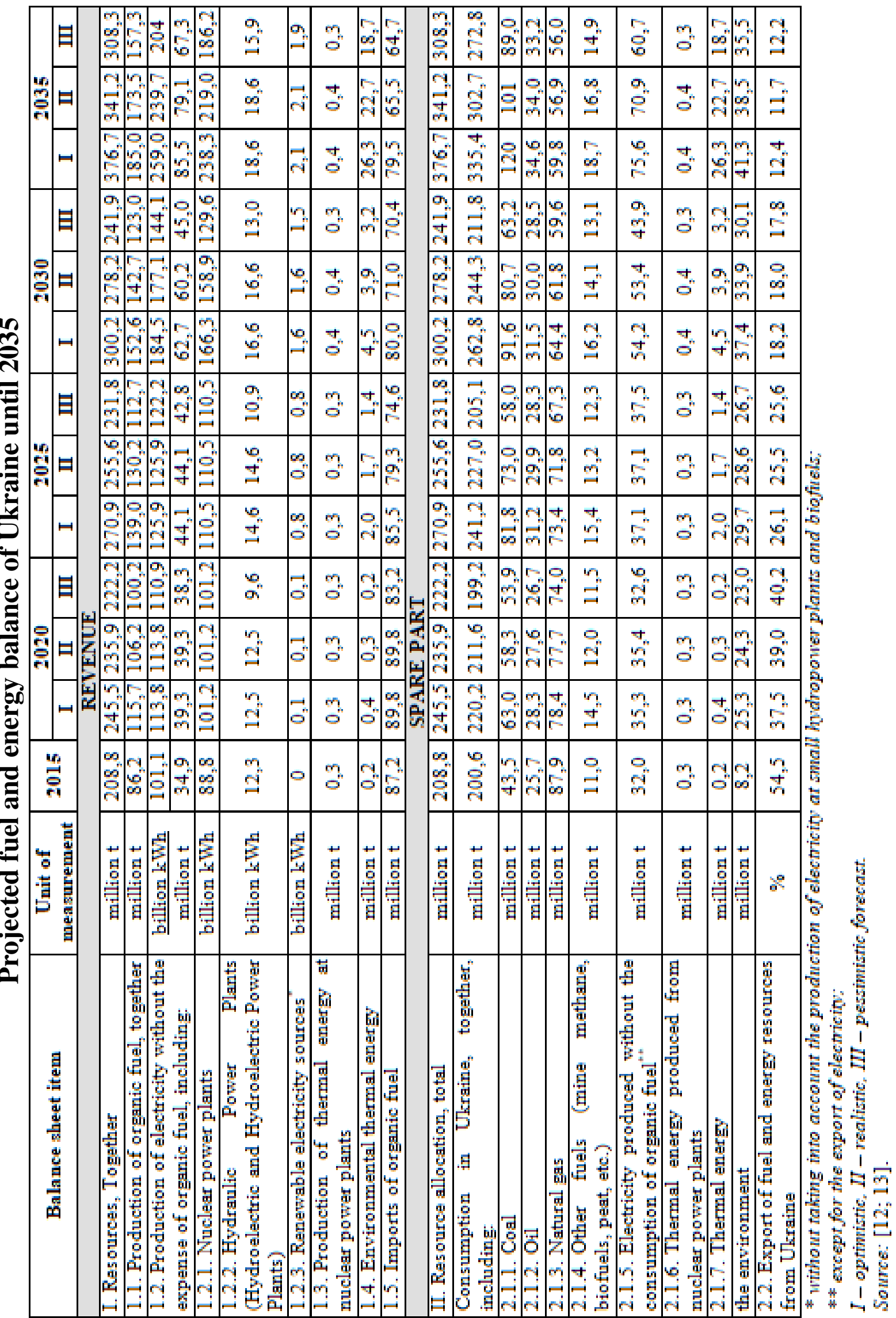


To solve these problems, a model of regulation and reform of the energy market was proposed, based on the configuration regulation and reform of the energy market (Figure 6).

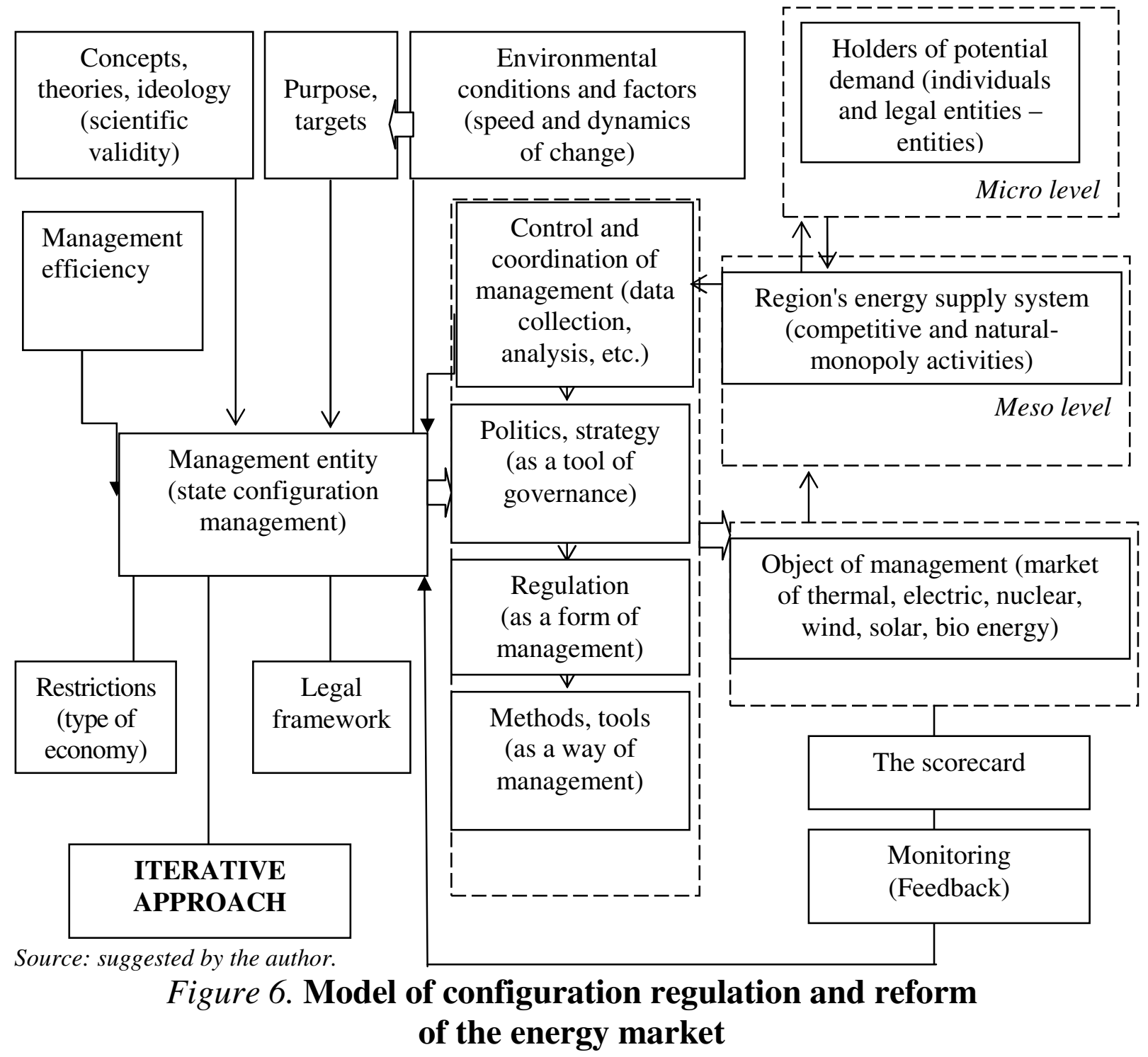

In the proposed model of state configuration regulation / reform of the energy market (Figure 6), special attention should be paid to control and coordination at the regional (meso) level, where the demand for energy resources from primary sources (potential demand carriers) and sectoral (meso) potential can be tracked online) levels where the supply of energy resources is formed before observing changes and the formation of needs directly at the enterprise level (micro level). All this in a complex allows to make the necessary decisions at the national (state) level (within the limits of their competences) faster, reducing the time of decision-making and increasing the efficiency of regulation / reform in general. That is, regional and sectoral levels of state 
regulation act as a buffer zone in the system of regulatory hierarchy, more significant and operational. In addition, at the regional level, the principles of territorial approach are implemented, and at the sectoral level, together with industry indicators, they provide more complete and qualitative information to the regulated entity on the functioning of the system of regulation / reformation of the energy market in the complex.

In line with the decentralization of power and increasing the role and importance in the economic process of the regions, it is necessary to have a competent combination of the benefits of sectoral and territorial state regulation / reform of the energy market in Ukraine.

At the same time, domestic and foreign economic experience confirms the existence of these problems in public administration and determines the search for their solution by building a more modern and progressive model of regulation / reform of the energy market.

Configuration regulation / reform is possible in cases where, firstly, it is necessary to improve the quality of regulation / reform in difficultly predicted external and internal environments; secondly, when there is a need to continue the life cycle of the created configuration (modifying and refining its constituent elements), thirdly, when there is a need for an adequate and timely response to global challenges.

In this case, the configuration should be understood not only a set of different documents, methods and means of influence on the object of regulation, but also the process of regulation of the operation and development of large and complex objects both from a technical and technological point of view, as well as from organizational and production.

In this regard, there are several features that characterize the state configuration regulation and distinguish it from other (previous) types of energy market regulation.

The implementation of state configuration regulation / reform of the energy market is based not only on regulatory (legislative) instruments and various restrictions (eg, type of economy), but also an iterative approach characterized by the implementation of a certain sequence of steps - iterations. Each iteration involves part of the process of regulating the functioning and development of the energy market. At the same time, each regular iteration is built on the basis of the previous iterations, improving the regulation / reform until the final targets are reached. The iterative approach allows: a) timely account for constant changes occurring in the external and internal environment; $b$ ) to reduce the time spent on processing in the case of emergency work at the end of the financial year; c) to reduce the share of risk in the first stages of functioning of the energy supply system of the economy (in case something goes wrong); d) make tactical changes to the configuration in a timely manner; e) carry out pilot design in 
selected regions / industries in order to eliminate defects in the operation of the energy supply system and energy use.

The speed and dynamics of changes in environmental conditions can so strongly affect the functioning of the energy market that changing targets in the short term becomes natural. The final consumers of energy resources and specific goods are natural (households) and legal entities (enterprises and organizations), which are carriers of potential demand. Therefore, they form the quantity and volume of supply on the commodity market (based on the specifics of the commodity - energy, and taking into account the balance of production and consumption), that is, essentially, act as the subject of regulation. Such an understanding of interaction in the market of sellers and buyers suggests the presence of subject-subject relations within the management process.

Conclusions and suggestions. The proposed mechanism and instruments for regulating / reforming the energy market, including organizational measures (reduction of dependence on the oil and gas market; decommissioning of capacities created within the previous large investment cycle; liberalization of the energy market in the distribution sector; elimination of generation deficits; continued liberalization of distributed generation), technological (creation of local networks with generation from renewable sources; Smart grid versions "active adoption of standards of "passive, active homes"; formation of the electricity storage market) and financial (attraction of large investments in the energy sector; introduction of project financing technologies to attract long-term investment resources of the banking system; creation of special economic zones in order to minimize the tax burden subjects of economic activity within the framework of the implementation of the state policy in energy saving) stimulation of the development of efficient energy, energy systems erezhennya, with systematic nature, will allow to fully reach the strategic guidelines set out in the Energy Strategy of Ukraine for the period up to 2030 [14].

\section{References}

1. Pro osnovy natsionalnoi bezpeky Ukrainy: Zakon Ukrainy vid 01.07.2010 № 2411-VI [On the basics of national security of Ukraine: Law of Ukraine dated 01.07.2010 № 2411-VI]. Retrieved from: http://www.rnbo.gov.ua/content/zakon_ onbu.html [in Ukrainian].

2. Beliaev, L.S. (2009). Problemy energeticheskogo rynka [Energy Market Challenges]. Novosibirsk: Nauka. 296 p. [in Russian].

3. Mytsa, N.V. (2012). Vazheli derzhavnoho rehuliuvannia rynku enerhoresursiv [The importance of the sovereign regulation of the energy market]. Retrieved from:

\section{Література}

1. Про основи національної безпеки України: Закон України від 01.07.2010 № 2411-VI [Електронний ресурс]. Режим доступу: http://www.rnbo.gov. ua/content/zakon_onbu.html.

2. Беляев Л. С. Проблемы энергетического рынка / Л. С. Беляев. - Новосибирск: Наука, 2009. - 296 с.

3. Мица Н. В. Важелі державного регулювання ринку енергоресурсів [Електронний ресурс] / Н. В. Мица. Режим доступу: http://archive.nbuv.gov. 
http://archive.nbuv.gov.ua/portal/soc_gum/inek/20 12_2/306.pdf [in Ukrainian].

4. Tovazhnianskyi, L.L., Shevchenko, B.O. (2009). Palyvno-enerhetychnyi kompleks. Stratehiia rozvytku [Salt-energy complex. Development Strategy]. Kharkiv: NTU «KhPI». 400 p. [in Ukrainian].

5. Franchuk, I.A. (2009). Osoblyvosti mekhanizmu derzhavnoho rehuliuvannia enerhetyky yak pryrodnoi monopolii [Features of the mechanism of sovereign regulation of energy as a natural monopoly]. Ekonomika ta Derzhava [Economy and Power], Vol. 2, P. 79-81 [in Ukrainian].

6. Alymov, O.M., Danylenko, A.I., Trehobchuk, V.M. et al. (2005). Ekonomichnyi rozvytok Ukrainy: instytutsionalne ta resursne zabezpechennia: monohrafiia [Economic Development of Ukraine: Institutional and Resource Security: Monograph]. Kyiv: About the Institute of Economics of the National Academy of Sciences of Ukraine. 540 p. [in Ukrainian].

7. Bakumenko, V., Kniaziev, V., Surmin, Yu. (2000). Metodolohiia derzhavnoho upravlinnia: problemy stanovlennia ta podalshoho rozvytku [Methodology of sovereign governance: problems of becoming and falsely developed]. Visnyk UADU [News of UAUD], No. 1, P. 11-27 [in Ukrainian].

8. Amelnytska, O.V. (2008). Mekhanizmy upravlinnia vyrobnycho-hospodarskoiu diialnistiu lokalnykh elektrychnykh merezh [Mechanisms of managing virobnichno-gospodarsky dyal'nistyu of local electrical measures: an abstract of the dissertation of a candidate of economic sciences: specialty 08.00.04 - Economy and management of consumer goods (behind the galleys)]. Donetsk. 20 p. [in Ukrainian].

9. Busariev, D.V. (2011). Strukturna asymetriia svitovoho enerhetychnoho balansu [Structurnal asymmetry of the energetic energy balance]. Ekonomika ta derzhava [Economy and Power], No. 11, P. 111-113 [in Ukrainian].

10. Vikhrov, O.P. (2015). Okremi pytannia reformuvannia rynku elektroenerhii $\mathrm{v}$ konteksti vykonannia Uhody pro asotsiatsiiu enerhoresursiv [Selected Issues of Reforming the Electricity Market in the Context of Implementation of the Association Agreement on Energy Resources]. Economic and Legal Research in the 21st ua/portal/soc_gum/inek/2012_2/306.pdf.

4. Товажнянський Л. Л.

Паливноенергетичний комплекс. Стратегія розвитку / Л. Л. Товажнянський, Б. О. Шевченко. - Харків: НТУ «ХПІ», 2009. - $400 \mathrm{c}$.

5. Франчук I. А.

Особливості

механізму державного регулювання енергетики як природної монополії / I. А. Франчук // Економіка та Держава. - 2009. - Вип. 2. - С. 79-81.

6. Економічний розвиток України: інституціональне та ресурсне забезпечення: монографія / О. М. Алимов, А. І. Даниленко, В. М. Трегобчук та ін. - К.: Об' єднаний інститут економіки НАН України, 2005. - 540 с.

7. Бакуменко В. Методологія державного управління: проблеми становлення та подальшого розвитку / В. Бакуменко, В. КнязєВ, Ю. Сурмін // Вісник УАДУ. - 2000. - № 1. - С. 1127.

8. Амельницька О. В. Механізми управління виробничо-господарською діяльністю локальних електричних мереж: автореф. дис... канд. екон. наук: спец. 08.00.04 - Економіка та управління підприємствами (за галузями) / О.В. Амельницька. Донецьк, 2008. - 20 с.

9. Бусарєв Д. В. Структурна асиметрія світового енергетичного балансу / Д. В. Бусарєв // Економіка та держава. - 2011. - № 11. - С. 111-113.

10. Віхров О. П. Окремі питання реформування ринку електроенергії в контексті виконання Угоди про асоціацію енергоресурсів [Електронний ресурс] / О. П. Віхров // Економіко-правові дослідження в XXI столітті: розвиток господарського 
Century: Development of Economic Legislation in the Context of Implementation of the Association Agreement of Ukraine with the European Union: Proceedings of the 15th International Scientific and Practical Internet Conference, December 816 2015. Kyiv. Retrieved from: http://hozpravo. com.ua/conferences/uchastnik/index.php?ELEME NT_ID=779 [in Ukrainian].

11. Kontseptsiia «zelenoho» enerhetychnoho perekhodu Ukrainy do 2050 roku [The concept of a green energy transition of Ukraine to 2050]. Ministry of Energy and Environment. Retrieved from: http://mpe.kmu.gov.ua/minugol/doccatalog/ document?id=245435016 [in Ukrainian].

12. Derzhavna sluzhba statystyky Ukrainy [State Statistics Service of Ukraine]. Retrieved from: http://www.ukrstat.gov.ua [in Ukrainian].

13. Statystychna informatsiia [Statistical Information]. Ministry of Energy and the Environment. Retrieved from: http://mpe.kmu.gov.ua [in Ukrainian].

14. Povidomlennia pro obhovorennia proektu onovlenoi «Enerhetychnoi stratehii Ukrainy na period do 2030 roku» [Communication on the discussion of the draft updated Energy Strategy of Ukraine for the period up to 2030]. Ministry of Energy and Coal Industry of Ukraine. Retrieved from: http://mpe.kmu.gov.ua/fuel/control/uk/ publish/article?art_id=222035 [in Ukrainian]. законодавства в контексті виконання Угоди про асоціацію України 3 Європейським Союзом: матеріали XV Міжнар. наук.-практ. інтернет-конф., 8-16 груд. 2015 р. - Київ, 2015. Режим доступу: http://hozpravo.com.ua/ conferences/uchastnik/index.php?ELEM ENT_ID=779.

11. Концепція «зеленого» енергетичного переходу України до 2050 року [Електронний ресурс] / Міністерство енергетики та захисту довкілля. Режим доступу: http://mpe.kmu.gov.ua/ minugol $/$ doccatalog/document $? \mathrm{id}=24543$ 5016.

12. Державна служба статистики України [Електронний ресурс]. - Режим доступу: http://www.ukrstat.gov.ua.

13. Статистична інформація [Електронний ресурс] / Міністерство енергетики та захисту довкілля. Режим доступу: http://mpe.kmu.gov.ua. 14. Повідомлення про обговорення проекту оновленої «Енергетичної стратегії України на період до 2030 року» [Електронний ресурс] / Міністерство енергетики та вугільної промисловості України. - Режим доступу: http://mpe.kmu.gov.ua/fuel/ control/uk/publish/article?art_id=222035. 